\title{
Effects of Forage Management on Pasture Productivity and Phosphorus Content
}

\author{
M. M. Haan, ${ }^{1}$ J. R. Russell, ${ }^{2}$ J. L. Kovar, ${ }^{3}$ W. J. Powers, ${ }^{4}$ and J. L. Benning ${ }^{5}$ \\ Authors are ${ }^{1}$ Assistant Scientist and ${ }^{2}$ Professor, Department of Animal Science, Iowa State University, Ames, IA 50010; ${ }^{3}$ Soil Scientist, USDA-ARS \\ National Soil Tilth Laboratory, Ames, IA 50011; ${ }^{4}$ Professor, Department of Animal Science, Michigan State University, East Lansing, MI 48824; and \\ ${ }^{5}$ Extension Water Quality Educator, University of Nebraska, Lincoln, NE 68583.
}

\begin{abstract}
The objectives of the current study were to determine the amounts of above- and below-ground plant biomass production, $\mathrm{P}$ uptake by forage, and P concentration of cool-season grass forage as influenced by management and season. Five forage management treatments were evaluated over 3 years in smooth bromegrass (Bromus inermis Leyss) pastures. Management practices were: ungrazed (U), hay harvest/fall stockpile grazing (HS), rotational stocking to residual sward heights of 10 (10R) or $5(5 \mathrm{R}) \mathrm{cm}$, and continuous stocking to maintain sward height at $5 \mathrm{~cm}(5 \mathrm{C})$. Forage samples were hand-clipped within and outside grazing exclosures monthly from April through November of each year and analyzed for mass and P concentration. Root samples were collected at the initiation and completion of the study for determination of root length density (RLD) and root surface area density (RSAD). Phosphorus concentrations of forage outside the grazing exclosures did not differ among 5C, 5R, and 10R treatments, which were greater than U paddocks in April and August and less than HS paddocks in June. Mean annual forage productivity was greater in HS, $10 \mathrm{R}, 5 \mathrm{R}$, and $5 \mathrm{C}$ paddocks $\left(6744 \pm 62 \mathrm{~kg} \cdot \mathrm{ha}^{-1}\right.$ mean $\left.\pm \mathrm{SE}\right)$ than in the U paddocks $\left(1872 \pm 255 \mathrm{~kg} \cdot \mathrm{ha}^{-1}\right)$. Mean P concentration of forage outside exclosures was greatest during the spring $(0.21 \pm$ $0.01 \%)$, and lowest during the fall $(0.13 \pm 0.01 \%)$. Mean annual $\mathrm{P}$ uptake by forage followed the same trend as forage production, being greater in the HS, $10 \mathrm{R}, 5 \mathrm{R}$, and $5 \mathrm{C}$ paddocks $\left(13.9 \pm 2.0 \mathrm{~kg} \cdot \mathrm{ha}^{-1}\right)$ than in the $\mathrm{U}$ paddocks $(3.7 \pm 0.5 \mathrm{~kg}$. $\left.\mathrm{ha}^{-1}\right)$. After 3 years, RLD decreased in the ungrazed paddocks, but was unchanged in the HS, 10R, 5R, and 5C paddocks. Forage production and $\mathrm{P}$ uptake by forage is stimulated by forage harvest, either by grazing or hay harvest in smooth bromegrass pastures.
\end{abstract}

\section{Resumen}

Los objetivos del presente estudio fueron determinar la influencia del manejo y época del año en las cantidades de producción de biomasa aérea y subterránea, la absorción de $\mathrm{P}$ por las plantas y la concentración de $\mathrm{P}$ en el forraje de especies de crecimiento invernal. Cinco tratamientos de manejo del forraje se evaluaron durante 3 años en praderas de "Smooth bromegrass" (Bromus inermis Leyss). Las practicas de manejo fueron: sin apacentamiento (U), cosecha de heno/apacentamiento en otoño del forraje almacenado en pie (HS), apacentamiento rotacional hasta dejar una altura de la pradera de $10 \mathrm{~cm}(10 \mathrm{R})$ o $5 \mathrm{~cm}(5 \mathrm{R}) \mathrm{y}$ apacentamiento continuo para mantener la pradera a $5 \mathrm{~cm}$ de altura (5C). Mensualmente, de abril a noviembre de cada año, se tomaron muestras de forraje, cortadas manualmente, dentro y fuera de exclusiones contra apacentamiento, y se analizaron para determinar la biomasa y concentración de P. Se colectaron muestras de raíz al inicio y final del estudio para determinar la densidad de longitud de la raíz (RDL) y la densidad del área de la superficie de la raíz (RSAD). Las concentraciones de P del forraje fuera de las exclusiones no difirieron entre los tratamientos 5C, 5R y 10R, las cuales fueron mayores que la de los potreros sin apacentamiento (U) en abril y agosto y menores que la de los poteros HS en junio. La productividad media anual de forraje fue mayor en los tratamientos HS, 10R, 5R, y 5C (6 $744 \pm 62 \mathrm{~kg} \cdot \mathrm{ha}^{-1}$ media \pm SE) que en los U (1 $872 \pm 255 \mathrm{~kg}$. $\left.\mathrm{ha}^{-1}\right)$. La mayor concentración media de P del forraje fuera de las exclusiones ocurrió durante la primavera $(0.21 \pm 0.01 \%)$ y la menor en otoño $(0.13 \pm 0.01 \%)$. La absorción media anual de P por el forraje siguió la misma tendencia que la producción de forraje, siendo mayor en los potreros HS, 10R, 5R y 5C (13.9 $\left.\pm 2.0 \mathrm{~kg} \cdot \mathrm{ha}^{-1}\right)$ que en los potreros U $\left(3.7 \pm 0.5 \mathrm{~kg} \cdot \mathrm{ha}^{-1}\right)$. Después de 3 años, la RLD disminuyó en los potreros sin apacentamiento, pero permaneció sin cambio en los potreros HS, 10R, 5R, y 5C. La producción y absorción de P son estimulados por la cosecha de forraje, ya sea mediante el apacentamiento o cosecha de heno de las praderas de "Smooth bromegrass."

Key Words: forage quality, grazing, root length density, rotational stocking

Research was funded in part by the lowa Agricultural and Home Economics Experiment Station, Ames, lowa; and by grants from the lowa Dept of Natural Resources through a grant from the US Environmental Protection Agency under the Federal Nonpoint Source Management Program (Section 319 of the Clean Water Act), lowa State University Leopold Center for Sustainable Agriculture, and the lowa State Water Resources Research Institute.

Correspondence: James Russell, Dept of Animal Science, lowa State University, 337 Kildee Hall, Ames, IA 50010. Email: jrussel|@iastate.edu

Manuscript received 1 May 2006; manuscript accepted 24 February 2007.

\section{INTRODUCTION}

Phosphorus $(\mathrm{P})$ is an essential nutrient for both plants (Cole et al. 1977) and animals (NRC 1996). However, excess $P$ in the environment has the potential to cause environmental degradation through contamination of surface waters, and represents an economic loss to producers through the purchase of fertilizer for crops or mineral supplements for livestock (CAST 2002). 
Therefore, it is important to manage pastures to optimize $\mathrm{P}$ availability for grazing cattle.

Pierzynski and Logan (1993) reported a large range in the average $\mathrm{P}$ concentration and $\mathrm{P}$ removal in harvested forages for several common forage species. The actual $\mathrm{P}$ content of forage varies with seasonal forage growth dynamics (Grings et al. 1996), P content of the soil (Nash and Halliwell 1999), soil P desorption kinetics (Raven and Hossner 1994), available $\mathrm{N}$ in the soil (Belanger et al. 2002), application of fertilizer P (Toor et al. 2004), soil moisture and ambient temperature (Cole et al. 1977; Kerrigde et al. 1990; Wadsworth et al. 1990), plant maturity (Grings et al. 1996), grazing pressure (Chaneton et al. 1996), and forage species (Pierzynski and Logan 1993). The variation in $\mathrm{P}$ content of forage under different conditions is related to the ability of the plant to assimilate $\mathrm{P}$ across the root (Cole et al. 1977), the presence of actively growing meristematic tissue (Wilman 2004), the leaf to stem ratio of the plant, and the amount of dead tissue in the plant (Greene et al. 1987).

In some instances, grazing can stimulate forage productivity by enhancing nutrient cycling through increased physical deterioration and soil incorporation caused by the consumption and excretion of forage nutrients and the action of hooves on the soil surface (Schuman et al. 1999). DeMezancourt et al. (1998) proposed that forage productivity at first increases with grazing pressure, reaches a maximum at a moderate rate of herbivory, and declines as grazing pressure increases. In an analysis of forage productivity from 127 grazed grassland studies, Milchunas and Lauenroth (1993) found that although grazing of livestock resulted in a $23 \%$ reduction in annual forage production, $17 \%$ of the studies showed a positive relationship between grazing and forage production. Studies that showed increased forage production resulting from grazing had low levels of consumption, were conducted for a limited number of years, and most had small increases in production.

Grazing not only impacts above-ground productivity, but below-ground productivity as well. Grazing pressure increased root mass in more sites than it decreased root mass (Milchunas and Lauenroth 1993), resulting in a mean increase of $20 \%$ in root mass with grazing across all studies. Root masses in the upper $60 \mathrm{~cm}$ of soil surface of smooth bromegrass (Bromus inermis Leyss) pastures were greater at medium grazing pressure than either heavy or light grazing pressure, whereas root mass of meadow bromegrass (Bromus biebersteinii Roem. \& Schult.) was greatest under light grazing pressure (Mapfumo et al. 2002).

Well-managed forage systems have the potential to increase plant production and the nutritional quality of forage (Pedreira et al. 1999), and therefore should increase the amount of $\mathrm{P}$ available to grazing animals (Wilman 2004), reducing the need for supplemental P. The objectives of the current study were to evaluate the effects of grazing management and season on the production of above-ground plant biomass production, root density, and the $\mathrm{P}$ uptake and concentration of forage in pastures dominated by smooth bromegrass.

\section{MATERIALS AND METHODS}

\section{Site Description}

For 3 years (2001-2003), smooth bromegrass pastures located at the Iowa State University Rhodes Research and Demonstra- tion Farm (lat $42^{\circ} 00^{\prime} \mathrm{N}$, long $93^{\circ} 25^{\prime} \mathrm{W}$ ) were managed to determine the impacts of grazing on forage production and $\mathrm{P}$ uptake (Haan et al. 2006). Soils at the study site were Downs silt loam (fine-silty, mixed, mesic Mollic Hapludalf), Gara loam (fine-loamy, mixed, mesic Mollic Hapludalf), and ColoEly complex (fine-silty, mixed, mesic, Cumulic Haplaquoll, and fine-silty, mixed, mesic, Cumulic Hapludoll). Thirty-year average annual precipitation at the research site was $891 \mathrm{~mm}$, with the majority of the precipitation (54\%) falling from May through August. Precipitation was slightly above average during the first $(932 \mathrm{~mm})$ and third $(965 \mathrm{~mm})$ year of the study and slightly below average during the second year (716 mm; NOAA 2001, 2002, 2003, 2004). Prior to initiation of the study, all pastures were managed as a single unit for beef cattle grazing and hay harvest for greater than 20 years.

Three pastures of approximately 2.2 ha on hillsides were subdivided into 5, 0.4-ha paddocks with a 6-m wide lane at the top of the hill for cattle movement. Soil samples were taken to a depth of $5 \mathrm{~cm}$ prior to the initiation of stocking in April 2001 for determination of Bray-1 P and exchangeable potassium (K). Based on soil test nutrient recommendations for cool-season grass pastures in Iowa (ISU 2002), P was applied as diammonium phosphate to two paddocks in one pasture to bring all paddocks to a minimum of an optimum P level (11$\left.15 \mathrm{mg} \cdot \mathrm{kg}^{-1}\right)$. Soils in all paddocks contained an optimum level (111-150 mg $\cdot \mathrm{kg}^{-1}$ ) or greater of exchangeable $\mathrm{K}$; therefore, no additional $\mathrm{K}$ was applied. Neither $\mathrm{P}$ nor $\mathrm{K}$ was applied for the remainder of the study period. In each year, $\mathrm{N}$ was applied as urea at a rate of $90 \mathrm{~kg} \mathrm{~N} \cdot \mathrm{ha}^{-1}$ before the initiation of grazing in the spring and $50 \mathrm{~kg} \mathrm{~N} \cdot \mathrm{ha}^{-1}$ at the initiation of the forage stockpiling period in August to all paddocks.

\section{Forage Management}

Forage management treatments were randomly assigned to 1 of 5 paddocks in each of the 3 replicated pastures. Treatments included: an ungrazed control (U), summer hay harvest with fall stockpiled grazing (HS), continuous stocking to a residual sward height of $5 \mathrm{~cm}(5 \mathrm{C})$, and rotational stocking to a residual sward height of $5(5 \mathrm{R})$ or $10(10 \mathrm{R}) \mathrm{cm}$. Paddocks were initially stocked with 3 nonpregnant mature Angus cows (mean $\pm \mathrm{SE}$ body weights of $657 \pm 84,613 \pm 94$, and $625 \pm 53 \mathrm{~kg}$ in year 1, 2, and 3, respectively) in May of all three years. Summer grazing was terminated in mid-October of each year. Animals had access to salt, but received no supplemental $\mathrm{P}$ while on the research pastures.

In the continuous stocking system, cattle were removed from the paddocks once the sward height, measured with a falling plate meter $\left(4.8 \mathrm{~kg} \cdot \mathrm{m}^{-2}\right)$, decreased to $5 \mathrm{~cm}$. Each $\mathrm{cm}$ of forage sward height, measured with the falling plate meter, corresponds to $112 \mathrm{~kg}$ of live forage dry matter per ha (Hermann et al. 2002). Paddocks were allowed a short rest period of 7 to 10 days to allow limited forage regrowth to occur. These short periodic rest periods in the continuous stocking system were considered to be representative of cattle distribution patterns in a larger pasture. Cattle allowed continuous access to a large pasture avoid areas of low forage availability in favor of areas of greater forage availability (Pinchak et al. 1991), effectively providing the area of low 
forage availability a short rest period for forage regrowth to occur. In the rotational stocking systems, cattle were removed from the paddocks when the sward height decreased to 5 or $10 \mathrm{~cm}$ for the $5 \mathrm{R}$ and $10 \mathrm{R}$ treatments, respectively. In both rotational stocking systems, paddocks were allowed 35-day rest periods to allow for plant regrowth before being restocked.

Hay was harvested from the HS treatment in June of each year. Regrowth from these paddocks was mowed in early August of each year at the beginning of the stockpiling period to improve forage quality during the stockpile grazing period (Fribourg and Bell 1984), but the yield of mowed forage was inadequate to harvest. Paddocks in the HS system were stocked in mid-November of each year following a killing frost and grazed to a residual sward height of $5 \mathrm{~cm}$ by 3 cows that had been used during the summer grazing period.

\section{Forage Sampling}

Forage sward heights were measured with a falling plate meter $\left(4.8 \mathrm{~kg} \cdot \mathrm{m}^{-2}\right)$ and forage samples were hand clipped to $2 \mathrm{~cm}$ from a $0.25-\mathrm{m}^{2}$ area at 6 random locations in all paddocks and inside $6,1.5-\mathrm{m}^{2}$ grazing exclosures in each grazed paddock in each month from April through November. Grazing exclosures were moved each month to a new location adjacent to the randomly selected sampling locations with an equal sward height to that of the hand-clipped forage at each location in the grazed paddocks. First harvest forage in the paddocks with the HS treatment was harvested as small square bales. All bales were weighed and half were randomly sampled with a $2.25-\mathrm{cm}-$ diameter Penn State forage sampler (NASCO, Fort Atkinson, WI) at harvest.

To determine initial and final root length density (RLD) and root surface area density (RSAD), soil cores were collected at the initiation of grazing in June 2001 and again in May 2004 after 3 grazing seasons. Hand probes with a $3.81-\mathrm{cm}$ diameter were used to collect 8 cores at random locations within each paddock. The cores were divided into 0 to $5 \mathrm{~cm}$ and 5 to $15-\mathrm{cm}$ depth increments. A hydro-pneumatic separation system was used to separate roots from soil (Smucker et al. 1982). After removing debris, plant residues, and dead roots, individual roots from each sample were stained and then scanned to obtain a digitized (TIF) image. Images were analyzed with the ROOTEDGE software (Kaspar and Ewing 1997) to obtain total root length and mean diameter. Root length density and root surface area density were calculated by dividing the root length and surface area by the volume of soil sampled.

\section{Laboratory Analysis and Calculations}

Forage samples, both hand-clipped pasture and hay core samples, were dried in a forced air oven at $65^{\circ} \mathrm{C}$ for 48 hours, weighed, and ground with a Wiley Mill (Arthur H. Thomas Co., Philadelphia, PA) to $2 \mathrm{~mm}$. Forage P was determined by combustion in a muffle furnace at $550^{\circ} \mathrm{C}$ for 4 hours, followed by an acid extraction of the ash with $6 \mathrm{~N}$ hydrochloric acid, a molybdovanadate reaction, and colorimetric determination against a standard curve (Spectronic Instruments, Rochester, $\mathrm{NY})$ at $400 \mathrm{~nm}$ (AOAC 1990).

Monthly forage dry matter yield and $\mathrm{P}$ accumulation in ungrazed paddocks were calculated as the differences in yield of these components between subsequent monthly forage samples.
Monthly forage dry matter yield and $\mathrm{P}$ accumulation in grazed paddocks were calculated as the differences between the yields of these components within the grazing exclosure at a specified month and outside the grazing exclosure in the previous month. Net forage dry matter yield and $\mathrm{P}$ accumulation from the U, 5C, 5R, and 10R paddocks were the sum of the monthly values determined by hand clipping. Net forage dry matter yield and $\mathrm{P}$ accumulation from HS paddocks were the sums of the dry matter yield and $\mathrm{P}$ accumulation in harvested hay and the monthly values, determined by hand clipping, after the forage was mowed in August. Because forage in paddocks with the HS treatment that was mowed in August was neither baled nor grazed, it was not included in the calculation of monthly or net forage dry matter yield and $\mathrm{P}$ accumulation.

\section{Statistical Analysis}

Data were analyzed using the PROC MIXED procedure of SAS (SAS 2001). The model included treatment, month, year, and their interactions as fixed effects. Replicate was treated as a random effect. Depth was included as a fixed effect when the root data were analyzed. Because root data followed a nonnormal distribution, statistical analyses were conducted with $\log _{10}$-transformed data. Differences between means were tested using a Tukey test for multiple comparisons. Least square means $( \pm$ SEM) are reported. Significance was determined at $P<0.05$ and a tendency for significance at $P<0.10$.

\section{RESULTS}

\section{Forage Sward Height, Mass, and P Concentration}

Mean sward heights of paddocks with the U treatment did not differ from paddocks with the HS and 10R treatments in April (Table 1$)$, but were greater $(P<0.05)$ than paddocks with all forage management treatments in May through November. Mean sward heights of paddocks with the 5C treatment did not differ from paddocks with other harvest treatments in April, paddocks with the $\mathrm{HS}$ and $5 \mathrm{R}$ treatment in May, paddocks with the HS treatment in June or paddocks with the 5R treatment in October and November, but were less $(P<0.05)$ than paddocks with all other treatments in July through September. Mean sward heights of paddocks with the 5R treatment did not differ from paddocks with the 10R treatment in April, June, and September, but were lower $(P<0.05)$ than paddocks with the $10 \mathrm{R}$ treatment in all other months. Mean sward heights of paddocks with the $10 \mathrm{R}$ treatment were greater $(P<0.05)$ than paddocks with the HS treatment after hay harvest in May and June, lower $(P<0.05)$ than paddocks with the HS treatment during the stockpiling period in October, but did not differ from paddocks with the HS treatment in other months.

Mean forage masses of paddocks with the 5C treatment did not differ from paddocks with the other forage harvest treatments in April, the HS and 5R treatment in May, and the $5 \mathrm{R}$ treatment in August, but were lower $(P<0.05)$ than other treatments in June, July, September, October, and November. Mean forage masses of paddocks with the 5R treatment did not differ from the HS treatment in April, May, July, and November and the 10R treatment in April and June, but were lower $(P<0.05)$ than the HS and $10 \mathrm{R}$ treatments in 
Table 1. Mean monthly forage sward heights $\left(\mathrm{SEM}^{1}=1.1\right)$, forage mass $(\mathrm{SEM}=235)$, and $\mathrm{P}$ concentration $(\mathrm{SEM}=0.02)$ of forage from outside of grazing exclosures in paddocks with different forage management treatments.

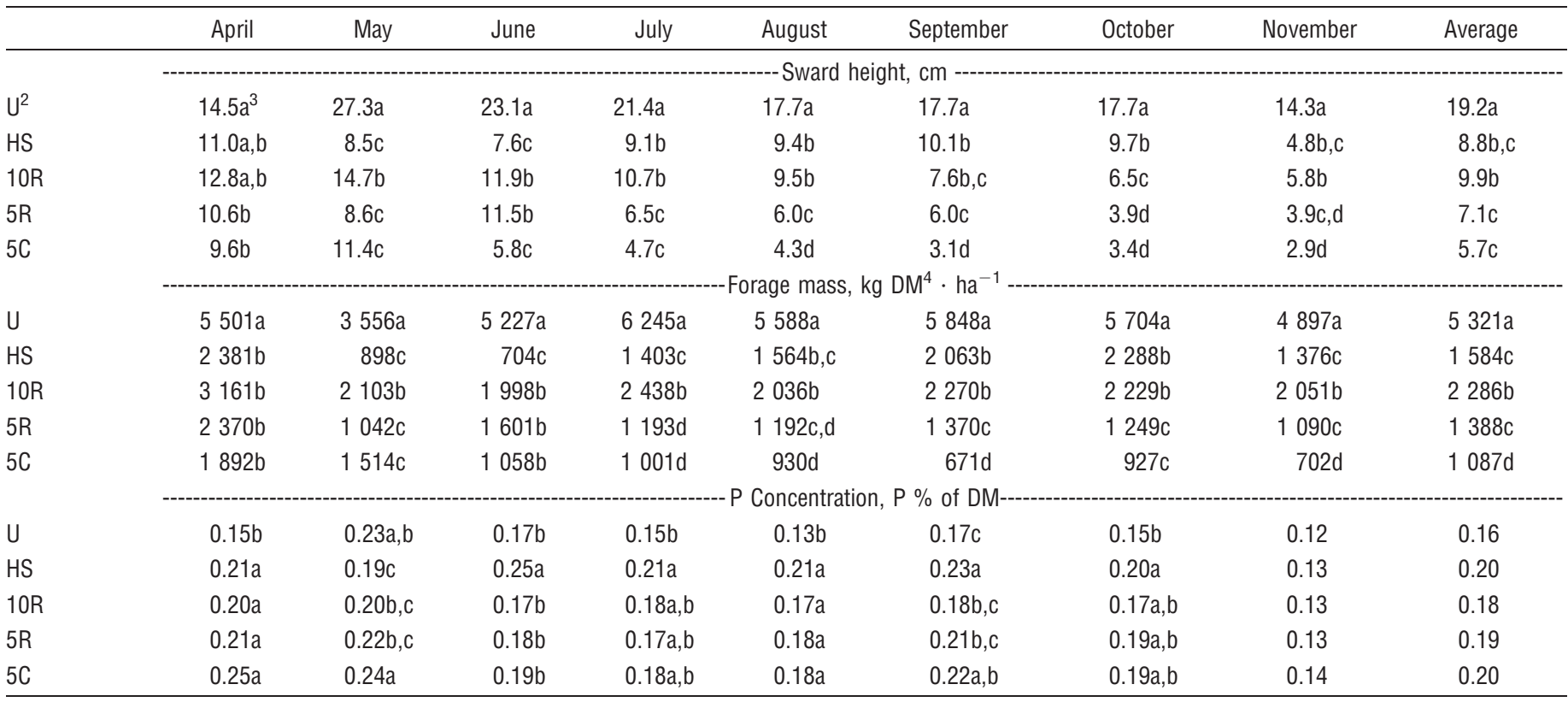

${ }^{1} \mathrm{SEM}=$ Standard error of the mean, $n=9$ (3 blocks $\times 3$ years).

${ }^{2}$ Forage management treatment: $U=$ ungrazed, $\mathrm{HS}=$ hay $/$ stockpile grazed, $10 \mathrm{R}=10 \mathrm{~cm}$ rotational, $5 \mathrm{R}=5 \mathrm{~cm}$ rotational, and $5 \mathrm{C}=5 \mathrm{~cm}$ continuous.

${ }^{3}$ Means within a column with different letters differ at $P<0.05$.

${ }^{4} \mathrm{DM}=$ Dry matter.

August, September, and October. Mean forage masses of paddocks with the HS treatment were lower $(P<0.05)$ than paddocks with the 10R treatment in April, May, June, July, and November, but did not differ from paddocks with the 10R treatment in August, September, and October.

Mean $\mathrm{P}$ concentrations of forage in paddocks with the $\mathrm{U}$ treatment were lower $(P<0.05)$ than all treatments in April and August, and lower $(P<0.05)$ than paddocks with the HS treatment in June, July, September, and October. Mean forage $\mathrm{P}$ concentration in paddocks with the HS treatment were lower $(P<0.05)$ than those with the $5 \mathrm{C}$ treatment in June, but greater $(P<0.05)$ than paddocks with the $10 \mathrm{R}, 5 \mathrm{R}$, and $5 \mathrm{C}$ treatments in June, and paddocks with the $5 \mathrm{R}$ and $5 \mathrm{C}$ treatments in September. Forage P concentration did not differ between the $10 \mathrm{R}, 5 \mathrm{R}$, and $5 \mathrm{C}$ treatment in any month. Minimum forage $\mathrm{P}$ concentration occurred in November for all treatments.

\section{Forage Production and P Uptake}

Annual forage production did not differ among harvested treatments $\left(6744 \pm 62 \mathrm{~kg} \cdot \mathrm{ha}^{-1} \cdot \mathrm{yr}^{-1}\right)$, but was greater $(P<$ $0.05)$ in harvested paddocks than in the $U(1872 \pm 255 \mathrm{~kg}$. $\mathrm{ha}^{-1} \cdot \mathrm{yr}^{-1}$ ) treatment (Table 2). Net forage production from paddocks with the HS treatment included $3202 \pm 186 \mathrm{~kg}$. $\mathrm{ha}^{-1} \cdot \mathrm{yr}^{-1}$ of forage that was harvested as hay. Forage production in the HS treatment might have been underestimated as a result of forage dry matter losses related to respiration and leaf losses associated with mowing and conditioning (Rotz and Muck 1994), and the loss of forage that was mowed, but not harvested in August to initiate stockpiling for winter grazing. Available forage allowed an average of $429,337,272$, and 63 cow-days $\cdot \mathrm{ha}^{-1}$ of grazing per year in the $5 \mathrm{C}, 5 \mathrm{R}, 10 \mathrm{R}$, and HS paddocks, respectively.

In the $5 \mathrm{C}, 5 \mathrm{R}$, and $10 \mathrm{R}$ paddocks, forage production was greatest $(P<0.05)$ during the spring, decreased during the summer, was negative in the fall, and began to increase again in the early spring (Fig. 1). Negative growth during the fall was likely the result of senescence and decay of forage. In the HS treatment, forage production was greatest $(P<0.05)$ in the month following hay harvest and then followed the same productivity pattern as occurred in the grazed paddocks. The $\mathrm{U}$ treatment was characterized as having several alternating periods of forage growth and decay throughout the year.

Similar to forage production, mean annual $\mathrm{P}$ uptake did not differ between harvested treatments $\left(13.9 \pm 2.0 \mathrm{~kg} \cdot \mathrm{ha}^{-1}\right.$. $\left.\mathrm{yr}^{-1}\right)$, and was greater $(P<0.05)$ than $\mathrm{U}\left(3.7 \pm 0.5 \mathrm{~kg} \cdot \mathrm{ha}^{-1}\right.$. $\mathrm{yr}^{-1}$ ) treatments (Table 2). Phosphorus uptake by forage was

Table 2. Annual forage production and $P$ uptake as affected by forage management practice in cool-season grass pastures.

\begin{tabular}{lcccccc}
\hline & $\mathrm{U}^{1}$ & $\mathrm{HS}$ & $10 \mathrm{R}$ & $5 \mathrm{R}$ & SC & SEM $^{2}$ \\
\hline Annual forage production, $\mathrm{kg} \cdot \mathrm{ha}^{-1}$ & $1872 \mathrm{~b}^{3}$ & $7116 \mathrm{a}$ & $6269 \mathrm{a}$ & $7160 \mathrm{a}$ & $6430 \mathrm{a}$ & 72 \\
Annual P uptake, $\mathrm{kg} \cdot \mathrm{ha}^{-1}$ & $3.7 \mathrm{~b}$ & $13.2 \mathrm{a}$ & $13.5 \mathrm{a}$ & $14.5 \mathrm{a}$ & $14.5 \mathrm{a}$ & 2.4 \\
\hline
\end{tabular}

${ }^{1}$ Forage management treatment: $\mathrm{U}=$ ungrazed, $\mathrm{HS}=$ hay $/$ stockpile grazed, $10 \mathrm{R}=10 \mathrm{~cm}$ rotational, $5 \mathrm{R}=5 \mathrm{~cm}$ rotational, and $5 \mathrm{C}=5 \mathrm{~cm}$ continuous.

${ }^{2} \mathrm{SEM}=$ Standard error of the mean.

${ }^{3}$ Means within a row with different letters differ at $P<0.05$. 


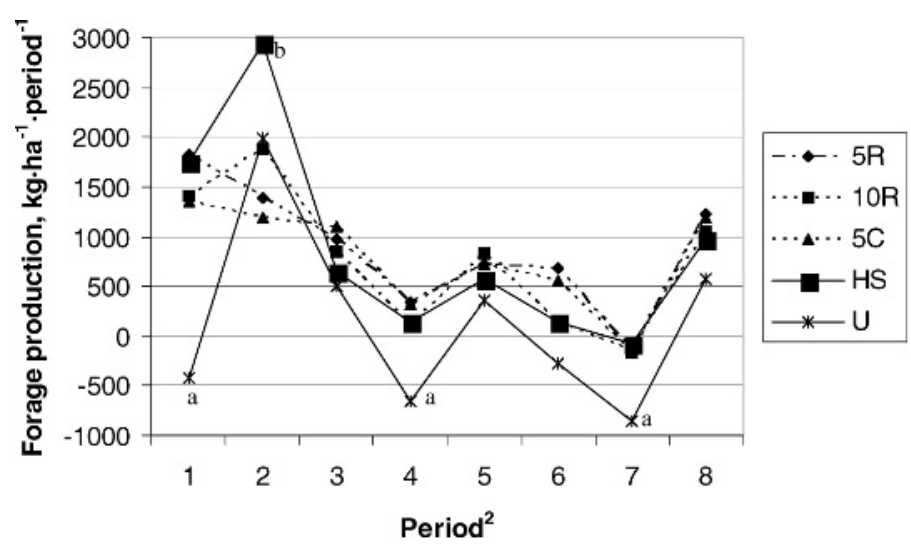

Figure 1. Net annual average forage production under different forage management practices $\left(\mathrm{SEM}^{1}=298\right)$. ${ }^{1} \mathrm{SEM}=$ Standard error of the mean, $n=9$ (3 blocks $\times 3$ years). ${ }^{2}$ Period of forage growth: $1=$ AprilMay, Period 2 = May-June, Period 3 = June-July, Period $4=$ JulyAugust, Period $5=$ August-September, period $6=$ September-October, period $7=$ October-November, period $8=$ November-April. $\mathrm{U}=$ ungrazed, $\mathrm{HS}=$ hay $/$ stockpile grazed, $10 \mathrm{R}=10 \mathrm{~cm}$ rotational, $5 \mathrm{R}=$

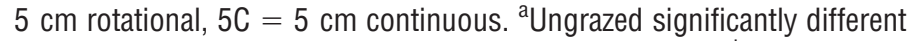
than 5R, 10R, 5C, and HS treatments $(P<0.05)$. ${ }^{\mathrm{b}}$ Hay/stockpile significantly different than $5 \mathrm{R}, 10 \mathrm{R}, 5 \mathrm{C}$, and $\mathrm{U}$ treatments $(P<0.05)$.

lower $(P<0.05)$ in $\mathrm{U}$ pastures, than in pastures harvested by grazing or as hay, during the spring through early summer and again during late fall (Fig. 2). Of the P uptake from paddocks with the HS treatment, $6.56 \pm 0.73 \mathrm{~kg} \cdot \mathrm{ha}^{-1} \cdot \mathrm{yr}^{-1} \mathrm{P}$ were harvested as hay.

\section{Grazing Effects on Root Characteristics}

Root length density (RLD) and root surface area density (RSAD) in the surface soil $(0-15 \mathrm{~cm})$ did not differ across the study area at the initiation of grazing. However, both RLD and RSAD were lower $(P<0.05)$ in the $5-15 \mathrm{~cm}$ layer than in the $0-5 \mathrm{~cm}$ layer. Among individual treatments, mean RLD in the $0-5 \mathrm{~cm}$ layer was lower $(P<0.05)$ in the $5 \mathrm{C}$ treatment than in the U and HS treatments (Fig. 3), but did not differ among treatments in 5-15 cm soil layer. Root surface area density, on the other hand, did not differ among treatments in either the 05 or $5-15 \mathrm{~cm}$ soil layers at the time of grazing initiation (data not shown).

After three years, RLD and RSAD did not differ in the surface soil, and although both RLD and RSAD decreased with profile depth, differences among individual treatments within the $0-5 \mathrm{~cm}$ and $5-5 \mathrm{~cm}$ layers were not evident (Fig. 3). Although mean root length density in the $0-5 \mathrm{~cm}$ layer of the $5 \mathrm{C}$ treatment was $16.2 \mathrm{~cm} \cdot \mathrm{cm}^{-3}$ greater than in the U treatment, this difference was not significant $(P=0.102)$ because of the variability of RLD among the paddocks of the $5 \mathrm{C}$ treatment $(\mathrm{CV}=30.4 \%)$.

To determine the effect of three grazing seasons on forage root characteristics, data from the initial and final sampling were compared. Root length density in the surface soil (0$15 \mathrm{~cm})$ decreased $(P<0.05)$ in the U, HS, 10R, and $5 \mathrm{R}$ treatments, but did not change in the $5 \mathrm{C}$ treatment. Root surface area density in the surface soil also decreased $(P<0.05)$ in the $U$ treatment, but did not change in any of the other treatments. Within each sampling depth, RLD decreased in

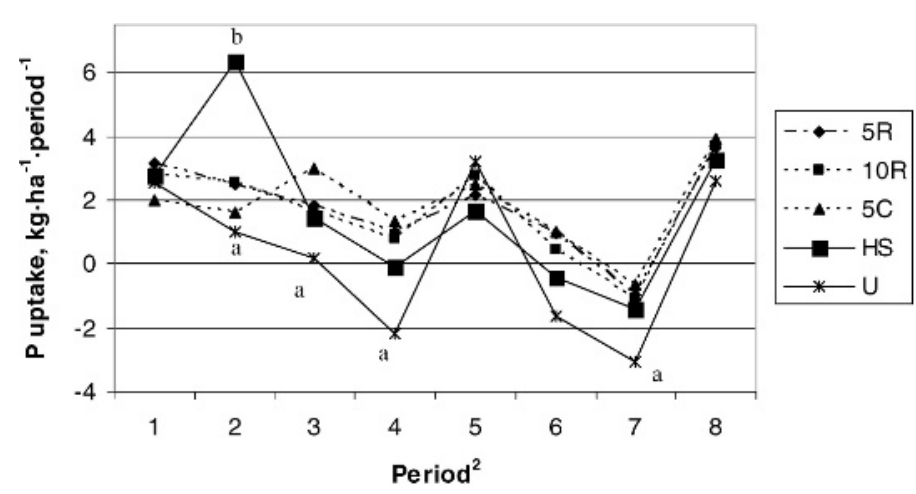

Figure 2. Net annual average $P$ uptake by forage under different management practices $\left(\mathrm{SEM}^{1}=0.703\right) .{ }^{1} \mathrm{SEM}=$ Standard error of the mean, $n=9$ (3 blocks $\times 3$ years). ${ }^{2}$ Period of $P$ uptake: $1=$ April-May, Period 2 = May-June, Period 3 = June-July, Period 4 = July-August, Period $5=$ August-September, period $6=$ September-October, period 7 $=$ October-November, period $8=$ November-April. $\mathrm{U}=$ ungrazed, $\mathrm{HS}=$ hay/stockpile grazed, $10 \mathrm{R}=10 \mathrm{~cm}$ rotational, $5 \mathrm{R}=5 \mathrm{~cm}$ rotational, $5 \mathrm{C}$ $=5 \mathrm{~cm}$ continuous. ${ }^{a}$ Ungrazed significantly different than $5 \mathrm{R}, 10 \mathrm{R}, 5 \mathrm{C}$,

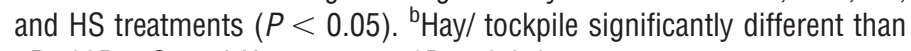
5R, 10R, 5C, and $U$ treatments $(P<0.05)$.

both the $0-5 \mathrm{~cm}$ and $5-15 \mathrm{~cm}$ layers of the $U$ treatment and the $5-15 \mathrm{~cm}$ layer of the $5 \mathrm{R}$ treatment. Root surface area density of the $5 \mathrm{C}$ treatment increased $(P<0.05)$ from $2.05 \mathrm{~cm}^{2} \cdot \mathrm{cm}^{-3}$ to $3.91 \mathrm{~cm}^{2} \cdot \mathrm{cm}^{-3}$. This increase suggests that overall root biomass in the $0-5 \mathrm{~cm}$ layer increased in these paddocks after three years of continuous grazing.

\section{DISCUSSION}

\section{Forage Characteristics}

Management and seasonal factors can interact to have significant impacts, both positive and negative, on the productivity

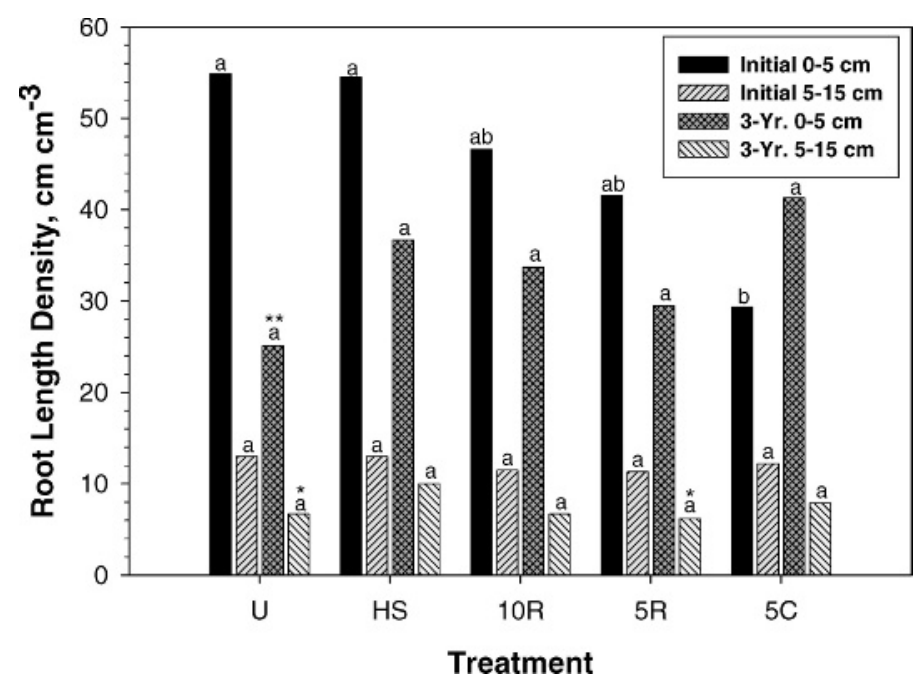

Figure 3. Effect of five grazing management systems on root length density in the surface soil. Bars within a sampling period and depth increment with the same letter are not significantly different at the 0.05 level. Bars within a treatment and depth increment with * and ** above are significantly different at the 0.05 and 0.01 level, respectively, from initial values. 
and quality of pastures and grasslands. The major actions of grazing animals on pasture are defoliation, treading, and removal or translocation of nutrients within pasture (Greenwood and McKenzie 2001). In addition to the actions of grazing, animal growth and nutritional characteristics of forages will change with maturity of the forage (Ferdinandez and Coulman 2001).

Clary and Leininger (2000) recommended a residual forage sward height of $10 \mathrm{~cm}$ as a starting point for forage management in order to maintain plant vigor and reduce environmental impacts associated with cattle grazing. This height can then be increased or decreased to meet the management needs of the specific location (Clary and Leininger 2000). In the current study, sward height in the U treatment remained above $14 \mathrm{~cm}$ for the entire year and sward heights in the $10 \mathrm{R}$ and HS treatments remained at approximately 9 to $10 \mathrm{~cm}$ for most of the grazing season before decreasing in the fall. Mean sward heights in the $5 \mathrm{R}$ treatment remained at or above $6 \mathrm{~cm}$ for the majority of the grazing season, but fell below $4 \mathrm{~cm}$ in October and November. Mean sward heights in the $5 \mathrm{C}$ treatment were below $5 \mathrm{~cm}$ for the majority of the grazing season, and dipped below $3 \mathrm{~cm}$ in November. Low stubble heights have been associated with an increase in bare soil (Papanastasis 1985) and in the current study, paddocks with the $5 \mathrm{C}$ treatment had greater bare soil than did the other treatments (Haan et al. 2006).

Low forage sward heights, as observed in the 5C treatment, can result in a reduction in forage intake (Tharmaraj et al. 2003). The use of rotational stocking systems allowed the maintenance of sward heights greater than 3.9 and $6.5 \mathrm{~cm}$ for paddocks with the $5 \mathrm{R}$ and $10 \mathrm{R}$ treatments until October, likely maintaining greater forage intake by the cattle throughout the season. Correll et al. (2003) observed that forage mass and digestibility of pasture grazed to a sward height greater than 5 , but less than $10 \mathrm{~cm}$ resulted in maximum forage intake by cattle.

A reduction in the concentrations of minerals, including $\mathrm{P}$, of forage occurs as forages mature (Kincaid and Cronrath 1983; Borman 2004). Changes in $P$ concentration associated with treatment and month in the current study were most likely related to changes in the cell wall concentration, leaf-to-stem ratio (Belanger et al. 2002) and live to dead ratio (Greene et al. 1987) of the available forage, although neither of these variables nor the $\mathrm{P}$ concentrations of specific forage tissues were measured in the current study. Nitrogen availability is also known to have a positive relationship with $\mathrm{P}$ concentration and uptake by forage (Hemingway 1999). This effect might partially be responsible for the slight increase in forage $\mathrm{P}$ concentration and increase in $\mathrm{P}$ uptake in September following the application of $\mathrm{N}$ in August.

Although changes in forage $\mathrm{P}$ concentration were observed over the growing season, $\mathrm{P}$ concentration of available forage was adequate at all times to meet the nutritional requirements of spring-calving beef cows with a moderate level of milk production, based on NRC (1996) requirements (Fig. 4). During early summer, while cows are still at high level of milk production, the forage $\mathrm{P}$ concentration and the cow requirements were approximately equal. However, this level of $\mathrm{P}$ intake should be adequate because although the concentration of $\mathrm{P}$ was determined in hand-clipped forage, cattle have the

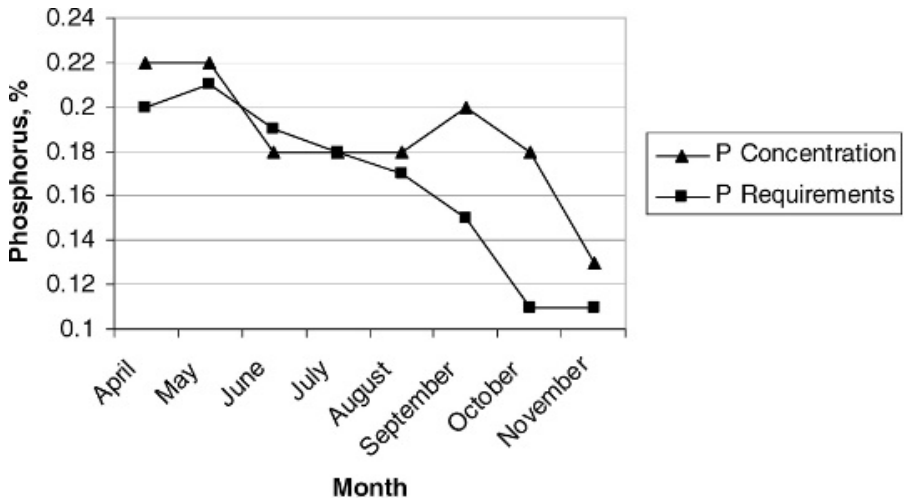

Figure 4. Comparison of the $P$ requirements of a spring-calving beef cow with $P$ concentration in forage. ${ }^{1}{ }^{1}$ Forage $P$ values are a pooled average of the three summer grazed paddocks in the current study. Animal requirements are based on NRC (1996) values for a spring (March) calving cow $(450 \mathrm{~kg})$ producing $9 \mathrm{~kg} \cdot \mathrm{d}^{-1}$ of milk at peak lactation.

ability to select forage with a greater nutritional value than the hand-clipped forage in pastures, assuming forage availability is adequate (Hermann et al. 2002).

\section{Forage Production and P Uptake}

Forage harvest has been shown to result in an increase in forage production compared to an unharvested pasture (Dormarr et al. 1997), as was observed in the current study. The greater forage productivity in grazed than ungrazed paddocks is likely caused by the grazed forage remaining in a vegetative or elongation stage for a longer time while the ungrazed pasture entered the reproductive growth stage. Additionally, grazing might stimulate productivity through enhanced nutrient cycling brought on by the physical deterioration, soil incorporation, and enhanced rate of decomposition caused by the consumption of forage and the excretion of nutrients in the manure, and the action of hooves on the soil surface (Schuman et al. 1999). Grazing cattle return to the pasture over $80 \%$ of $\mathrm{P}$ and other nutrients consumed in forage (Berry et al. 2001), and these nutrients become available to support forage growth (Bakker et al. 2004). In the current study, the amount of $\mathrm{P}$ deposited by the cattle was likely in excess of $80 \%$ because they were not lactating and were close to their mature body weights.

The trend of decreasing RLD (Fig. 3) and RSAD (data not shown) in the surface soil $(0-15 \mathrm{~cm})$ of the $U$ treatment might be the result of intraspecific competition. Mapfumo et al. (2002) suggested that intraspecific competition causes a reduction in root mass due to uncontrolled growth in an ungrazed pasture. Nie et al. (1997) also found that root biomass in the $0-5 \mathrm{~cm}$ soil layer significantly decreased under fallowed treatments, in which no grazing was allowed from spring to autumn, as compared to the grazed treatments.

Among the grazing treatments, few differences in RLD or RSAD were observed after three years of grazing. Manley et al. (1997) found similar results, because stocking rate and grazing treatment had no effect on above or below ground biomass in their 12-year study. The decrease in both RLD and RSAD in the $0-5 \mathrm{~cm}$ and $5-15 \mathrm{~cm}$ layers of the $\mathrm{U}$ treatment could indicate 
that roots grew deeper into the profile, as observed by Nie et al. (1997). The relatively shallower root systems of plants in the grazed pastures could be an indication of compaction during grazing (Shierlaw and Alston 1984). Nevertheless, this decrease in RLD and RSAD in all but the 5C treatment probably had little effect on the ability of the bromegrass to absorb water and nutrients or hold soil particles during heavy rainfall events.

Results of the current study also imply that forage productivity was not affected by stocking system. Carrying capacities of paddocks with the 10R, 5R, and 5C treatments were 272,337 , and $429 \mathrm{cow}$-days $\cdot \mathrm{ha}^{-1} \cdot \mathrm{yr}^{-1}$, respectively. Because forage production did not differ among grazing treatments, the increasing forage needs to support the greater carrying capacities of the $5 \mathrm{R}$ and $5 \mathrm{C}$ treatments were met by greater utilization of the existing forage as opposed to increased forage productivity. This greater forage utilization resulted in differences in forage masses and sward heights among the three summer grazing treatments at the end of the grazing season.

\section{Hay Harvest}

The mean removal rate of $\mathrm{P}$ by forage observed in the current study $\left(6.6 \mathrm{~kg} \cdot \mathrm{ha}^{-1}\right)$ were less than one half the 15 to $39 \mathrm{~kg}$. $\mathrm{ha}^{-1}$ reported for legume and cool-season grass hays reported by Pierzynski and Logan (1993). Both hay yield (3 $202 \mathrm{~kg}$. $\mathrm{ha}^{-1}$ ) and $\mathrm{P}$ concentration of harvested hay $(0.21 \%)$ in the current study were lower than the forage yields of 6720 to $13440 \mathrm{~kg} \cdot \mathrm{ha}^{-1}$ and P concentrations of $0.22 \%$ to $0.44 \%$ (Pierzynski and Logan 1993). Hay harvest can have major impacts on soil P content, causing the concentrations of plant available nutrients to decrease in the upper $15 \mathrm{~cm}$ of the soil profile (Mathews et al. 1994), although no reduction in plant available Bray-1 P was observed in the current study (Haan et al. 2006).

\section{MANAGEMENT IMPLICATIONS}

Forage production and $\mathrm{P}$ uptake by forage is stimulated by forage harvest, either by grazing animals or hay harvest. Although a grazing animal recycles most of the $\mathrm{P}$ it consumes to the pasture in the form of fecal $\mathrm{P}$, hay harvest results in the removal of $\mathrm{P}$ from the system. In pastures receiving a large application of $\mathrm{P}$ in the form of manure from livestock confinement feeding operations, regular hay harvest might be necessary to manage soil $\mathrm{P}$ so that it does not reach excessively high levels.

Forage $\mathrm{P}$ concentrations were adequate to meet the nutritional requirements for a spring-calving cow under all grazing management practices evaluated in the current study. However, in the 5C treatment, a short forage sward height might have limited forage intake and potentially affected animal performance. Rotational stocking systems may be better able to meet the nutritional requirements of moderate- to highproducing grazing animals. If an adequate amount of forage is available for grazing animals and soil $\mathrm{P}$ concentrations are at a level to support optimum plant growth, supplemental $\mathrm{P}$ should not be required for beef cows grazing smooth bromegrass pastures in the Midwest.

\section{ACKNOWLEDGMENTS}

The authors would like to thank the numerous graduate and undergraduate students who assisted with data collection and analysis and the Rhodes' farm staff for assistance with animal and pasture management.

\section{LITERATURE CITED}

AOAC. 1990. Official methods of analysis. 15th ed. Arlington, VA: Association of Official Analytical Chemists. 1200 p.

Bakker, E. S., H. Olff, M. Boekhoff, and J. M. Gleichman. 2004. Impact of herbivores on nitrogen cycling: contrasting effects of small and large species. Oecologia 138:91-101.

Belanger, G., A. Bregard, and R. Michaud. 2002. Phosphorus uptake and concentration of timothy genotypes under varying $\mathrm{N}$ applications. Crop Science 42:2044-2048.

Berry, N. R., P. L. Jewell, F. Sutter, P. J. Edwards, and M. Kreuzer. 2001. Effect of concentrate on nitrogen turnover and excretion of $\mathrm{P}, \mathrm{K}, \mathrm{Na}, \mathrm{Ca}$, and $\mathrm{Mg}$ in lactating cows rotationally grazed at high altitude. Livestock Production Science 71:261-275.

Borman, K. J. 2004. Effects of forage maturity on phosphorus digestion in beef cattle [thesis] Ames, IA: Iowa State University. $127 \mathrm{p}$.

[CAST] Council for Agricultural Science and Technology. 2002. Animal diet modification to decrease the potential for nitrogen and phosphorus pollution. Issue paper 21. Ames, IA. $16 \mathrm{p}$.

Chaneton, E. J., J. H. Lemcoff, and R. S. Lavado. 1996. Nitrogen and phosphorus cycling in grazed and ungrazed plots in a temperate subhumid grassland in Argentina. Journal of Applied Ecology 33:291-302.

Clary, W. P., AND W. C. Leininger. 2000. Stubble height as a tool for management of riparian areas. Journal of Range Management 53:562-573.

Cole, C. V., G. S. Innis, and J. W. B. Stewart. 1977. Simulation of phosphorus cycling in semiarid grasslands. Ecology 58:1-14.

Correll, O., J. Isselstein, and V. Pavlu. 2003. Studying spatial and temporal dynamics of sward structure at low stocking densities: the use of an extended rising-plate-meter method. Grass and Forage Science 58:450-454.

De Mezancourt, C., M. Loreau, and L. Abbadie. 1998. Grazing optimization and nutrient cycling: when do herbivores enhance plant production. Ecology 79(7):2242-2252.

DormarR, J. F., B. W. Adams, and W. D. Willms. 1997. Impacts of rotational grazing on mixed prairie soils and vegetation. Journal of Range Management 50:647-651.

Ferdinandez, Y. S. N., and B. E. Coulman. 2001. Nutritive values of smooth bromegrass, meadow bromegrass, and meadow $\times$ smooth bromegrass hybrids for different plant parts and growth stages. Crop Science 41:473-478.

Fribourg, H. A., and K. W. Bell. 1984. Yield and composition of tall fescue stockpiled for different periods. Agronomy Journal 76:929-934.

Greene, L. W., W. E. Pinchak, and R. K. Heitschmidt. 1987. Seasonal dynamics of mineral in forage at the Texas experimental ranch. Journal of Range Management 40:502-506.

Greenwood, K. L., And B. M. McKenzie. 2001. Grazing effects on soil physical properties and the consequences for pastures: a review. Australian Journal of Experimental Agriculture 41:1231-1250.

Grings, E. E., M. R. Haferkamp, R. K. Heitschmidt, and M. G. Karl. 1996. Mineral dynamics in forages of the Northern Great Plains. Journal of Range Management 49:234-240.

Haan, M. M., J. R. Russell, W. J. Powers, J. L. Kovar, and J. L. Benning. 2006. Grazing management effects on sediment and phosphorus in surface runoff. Rangeland Ecology and Management 59:607-615.

Hemingway, R. G. 1999. The effect of changing patterns of fertilizer applications on the major mineral composition of herbage in relation to the requirements of cattle: a 50-year review. Animal Science 69:1-18.

Hermann, M. L., J. R. Russell, and S. K. Barnhart. 2002. Evaluation of hay-type and grazing-tolerant alfalfa cultivars in season-long or complementary rotational stocking systems for beef cows. Journal of Animal Science 80:768-779. 
[ISU] lowa State University Extension. 2002. General guide for crop nutrient recommendations in lowa. PM 1688. Ames, IA: lowa State University. 19 p.

Kaspar, T. C., AND R. P. Ewing. 1997. ROOTEDGE: software for measuring root length from desktop scanner images. Agronomy Journal 89(6):932-940.

Kerrigde, P. C., M. A. Gilbert, and D. B. Coates. 1990. Phosphorus and beef production in northern Australia. 8. The status and management of soil phosphorus in relation to beef production. Tropical Grasslands 24:221-230.

Kincaid, R. L., and J. D. Cronkath. 1983. Amounts and distribution of minerals in Washington forages. Journal of Dairy Science 66:821-824.

Manley, W. A., R. H. Hart, M. J. Samuel, M. A. Smith, J. W. Waggoner, JR., and J. T. Manley. 1997. Vegetation, cattle, and economic responses to grazing strategies and pressures. Journal of Range Management 50:638-646.

Mapfumo, E., M. A. Naeth, V. S. Baron, A. C. Dick, and D. S. Chanasyk. 2002. Grazing impacts on litter and roots: perennial versus annual grasses. Journal of Range Management 55:16-22.

Mathews, B. W., L. E. Sollenberger, V. D. Nair, and C. R. Staples. 1994. Impact of grazing management on soil nitrogen, phosphorus, potassium, and sulfur distribution. Journal of Environmental Quality 23:1006-1013.

Milchunas, D. G., and W. K. Lauenroth. 1993. Quantitative effects of grazing on vegetation and soils over a global range of environments. Ecological Monographs 63(4):327-366.

Nash, D. M., ANd D. J. Halliwell. 1999. Fertilisers and phosphorus loss from productive grazing systems. Australian Journal of Soil Research 37:403-429.

[NOAA] National Oceanic and Atmospheric Administration. 2001. Climatological data: annual summary. Ashville, NC: United States National Oceanic and Atmospheric Administration. $36 \mathrm{p}$

[NOAA] National Oceanic and Atmospheric Administration. 2002. Climatological data: annual summary. Ashville, NC: United States National Oceanic and Atmospheric Administration. $36 \mathrm{p}$.

[NOAA] National Oceanic and Atmospheric Administration. 2003. Climatological data: annual summary Ashville, NC: United States National Oceanic and Atmospheric Administration. $36 \mathrm{p}$.

[NOAA] National Oceanic and Atmospheric Administration. 2004. Climatological Data: Annual Summary. Ashville, NC: United States National Oceanic and Atmospheric Administration. $36 \mathrm{p}$.

[NRC] National Research Council. 1996. Nutrient requirements of beef cattle. 7th rev. ed. Washington, DC: National Academy Press. 232 p.

Nie, Z. N., A. D.Mackay, I. Valentine, D. J. Barker, and J. Hodgson. 1997. Influence of pastoral fallow on plant root growth and soil physical and chemical characteristics in a hill pasture. Plant and Soil 197:201-208.
Papanastasis, V. P. 1985. Stubble height, basal cover, and herbage production relationships in grasslands of northern Greece. Journal of Range Management 38:247-250

Pedreira, C. G. S., L. E. Sollenberger, and P. Mislevy. 1999. Productivity and nutritive value of 'Florakirk' Bermudagrass as affected by grazing management. Agronomy Journal 91:796-801.

Pierzynski, G. M., and T. J. Logan. 1993. Crop, soil, and management effects on phosphorus soil test levels. Journal of Production Agriculture 6:513-520.

Pinchak, W. E., M. A. Smith, R. H. Hart, and J. W. Waggoner, JR. 1991. Beef cattle distribution patterns on foothill range. Journal of Range Management 44:267-275

Raven, K. P., and L. R. Hossner. 1994. Soil phosphorus desorption kinetics and its relationship with plant growth. Soil Science Society of America Journal 58:416-423.

Rotz, C. A., AND R. E. Muck. 1994. Changes in forage quality during harvest and storage. In: G. C. Fahey, Jr. [ED.]. Forage quality, evaluation, and utilization. Madison, WI: American Society of Agronomy. p 828-868.

SAS. 2001. SAS User's Guide. Statistics. Vers. 8. 2001. Cary, NC: SAS Inst. $3809 \mathrm{p}$.

Schuman, G. E., J. D. Reeder, J. T. Manley, R. H. Hart, and W. A. Manley. 1999. Impact of grazing management on the carbon and nitrogen balance of a mixedgrass rangeland. Ecological Application 9:65-71.

Shierlaw, J., and A. M. Alston. 1984. Effect of soil compaction on root-growth and uptake of phosphorus. Plant and Soil 77:15-28.

Smucker, A. J. M., S. L. McBurney, and A. K. Srivastava. 1982. Quantitative separation of roots from compacted soil profiles by the hydropneumatic elutriation system. Agronomy Journal 74:500-503.

Tharmaraj, J., W. J. Wales, D. F. Chapman, and A. R. Egan. 2003. Defoliation pattern, foraging behaviour and diet selection by lactating dairy cows in response to sward height and herbage allowance of a ryegrass-dominated pasture. Grass and Forage Science 58:225-238.

Toor, G. S., L. M. Condron, H. J. Di, K. C. Cameron, and J. T. Sims. 2004. Assessment of phosphorus leaching losses from a free draining grassland soil. Nutrient Cycling in Agroecosystems 69:167-184.

Wadsworth, J. C., R. W. Mclean, D. B. Coates, and W. H. Winter. 1990. Phosphorus and beef production in northern Australia. 5. Animal phosphorus status and diagnosis. Tropical Grasslands 24:185-196.

WILMAN, D. 2004. Some changes in grass crops during periods of uninterrupted growth. Journal of Agricultural Science 142:129-140. 